\title{
Tribute to Professor P.M.Udani
}

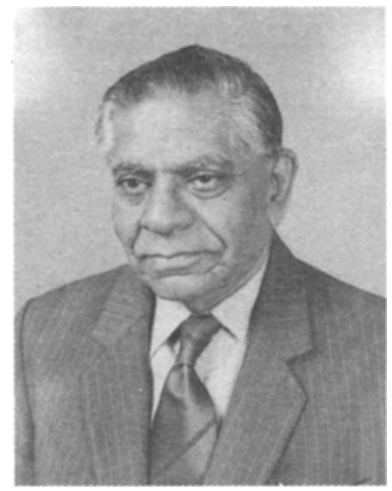

I am privileged to have worked closely with the late Dr.P.M.Udani for more than two decades, initially as a house physician, then as a registrar and thereafter on the faculty under his guidance at the Institute of Child Health, Grant Medical College and Sir J J Group of Hospitals, Mumbai. I continued as a faculty member even after his retirement, during which period, Dr.Udani was appointed as an Emeritus Professor and hence I remained in his proximity almost till the end of his illustrious life.

This long association with him gave me the opportunity to know many subtle qualities that he possessed. He was an astute clinician and I recall on many occasions how he would be able to spot a clinical diagnosis, which had baffled many clinicians. Dr.Udani was always invited at many centers in India and abroad and it used to be a feast of clinical rounds on his joining back as he would unveil hidden physical findings that were missed by other faculty members. His ward rounds would go on for several hours and used to be attended by many postgraduate students from other institutions. He was a born teacher, of a kind that is rare.

Dr.Udani was a voracious reader. He was always surrounded by books and journals in his office and his personal library at home had just enough room for him to sit in between loads of reference material spread all over. At every scientific meeting and conference, he would attend every lecture and make notes. His personal books had equal number of words scribbled by him on every vacant space on the page as many as those printed.

He was a prolific researcher and had several original contributions, which have been often quoted internationally. Especially, his work on tubercular meningitis has been a pioneering effort of many years of clinical and neuropathological correlation. Enthusiasm and devotion to science was his stronghold that would be impossible to match

He was a workaholic and continued to put in 14-16 hours of active work every day. He was a full time professor with very busy private practice. As a full time professor, he was required to work for 8 hours but Dr.Udani never left the department till late in the evening, only to reach his private office at odd hours and still attend to large number of patients who would throng his private office coming from far and wide. He seemed never to get tired of work. He always said jokingly that he was not a full time professor but a whole timer. I am sure every cell in his body survived on science and he breathed pediatrics till the end.

While he was a taskmaster, he was very loving to his students and always stood for them. I recall social evenings in his house every year where one could see different hues of the person, as he played harmonium and made every one at ease. As a typical scientist, he lived in a scientific "mess" oblivious of the surroundings and one could read a caption in his drawing room that said, "If you feel my house is untidy, this is in the best shape at present."

I pay my humble tribute to a man who was an extraordinary person as he excelled as a scientist, clinician, teacher, medical practitioner and above all a human being. May his soul rest in peace.

Y.K. Amdekar Jaslok Hospital \& Medical Research Center, Mumbai, E-mail : ykakr@vsnl.com 